Land, but, that it was visited previously by Baffin and by Cornelis Roule. His arguments are not at all borne out by the authorities to which he refers. Nor will the British Government be guided by any proposals not originating from those experienced arctic officers upon whose advice they rely, so that Dr. Petermann's suggestions about sendiug one steamer to the west coast and another to the cast coast of Greenland might liave been spared.

Iinglish geographers have always fully recognised the valuable services of Dr. Petermann as a cartographer, and the important and useful work he has long done in collecting and disseminating geographical information. But at the same time it cannot be forgotten that his persistent atherence to an indcfensible theory has retarded discovery, and that in 1865 his inopportune interference had a most injurious effect upon the prospects of arctic exploration from this country. That danger is at last overcome, but those who have borne the heat and burden of the day, cannot but protest against 3r. Petermann's present assumption of the position of an arctic anthorily and adviser.

Not. 22

Chemisis R, MakkHaM

\section{The Present State of the Arctic Ice Barriers}

In a letter from Capt. David Gray, quoted by Dr. Petermann (NATURE, vol. xi. p. 39), some very interesting observations on the arctic drift ice of this year's summer are recorded, which Capt. Gray regards as justifying the conclusion that "nearly the whole of the ice was driven out of the arctic basin last summer."

Capt. Gray's observations apper' to be limited to the coast of Greenland. If corresponding phenomena were presented in other and distant parts of the Arctic Ocean, they must afford stren confirmation of his conclusion. I have lately returned from a summer visit to Aretic Norway, having sailed round the North Cape and into the Varanger Fjord, stopping a few days at 'romsö and halting at ITammerfest, Vardo, Vadso, and other arctic stations, and I was muclis surprised at the curious difference between the climate $I$ found there this summer and that which I previously experienced at the same season.

The following extract describes the temperature between Tromso and IIammerfest during my first visit in July 1856 :"The weather was excessively hot. During the hottest part of the day the thermometer stood at $77^{\circ}$ in the cabin, at $92^{\circ}$ in the smoking saloon-a little cabin buitt on deck-and $\operatorname{los}^{\circ}$ in the sun : on shore, in the valleys, it must doubtless have been much fotter. The contrast of this claring Italian, or I might almost siy Irazilian sky, with the snow-clad rocks and glaciers dipping almost to the sea-edre, is vary striking. It was a continual source of wonderment; one of the few scenes which one does source of wonderment ; one of the accustomed to, but retains its novelty day after day." Such was the prevailing weather during the summer of 1856 , and sucl is the usual summer weather of Arctic Norway from and bucriming of July until a weeis o: two after the disappearance fhe midnight sun. This year it was miserably different, to the of the mappointment of the ladies I ventured to pilot thus far, great chappointment of the rotion to myself. The contrast was strikingly shown in and rexation to myself. The contrast was strikingly siown in two exctrsions up this valley with a forthight's interval. On both eccasions the lower part of the valley was a mud swamp from recent snow-thaw. In 1856 , three wecks earlier in the scason recent snow second visit this year, the snow water had evaporated, leaving the nath hard and dry. In 1856 , the poor little Lapps wore outside their huts, gasping with heat and varnished with oily perspiration; their huts were so insufferably hot that only one or two out of a party of seven ur eight male travellers dared to venture inside. This year, the ladies, as well as myself, were glad to warm ourselves by sitting round the hat fire upon the glanders that serve as chairs. Drizzling rain and cole mists replaced the oppressive heat, the brilliant sky, and rainless simmer-time of 1856.

The Duke of Roxburgh, who has spent sixteen stimmers in Arctic Norway (he has the Alten salmon river opening in lat. $\left.70^{\circ}\right)$, told me that the low tcmperature and drizaling mistiness of this summer was quite exceptional to his experience; that the summer of 1868 , which was memorably cold, was not so bad as this. The usual crops of rye and potatoes were expected to fail completely this summer.

This unusual summer is the more remarkable when compared with that of England, which, judying by the abundance of the wheat crop, must at least have reached, if not exceeded, the averaze of nucan warmth. 'The exceptional arctic summer must

$$
\text { * "Throngh Norway with a Kitapsack," p. } 5.39
$$

have been due to some exceptional arctic influence. The southward drifting of large quantities of polar ice, and consequent removal of some of the barriers that stand between us and the north pole, will account for what I have described, provided the loosened ice was sufficient in quantity and eastward extension.

The North Cape, though in lat. $71^{\circ}$, is not visited by icebergs; the sea there, and for some distance further north, is suffciently warmed by the Gulf Stream to remain quite open all the year through. The free northward exposure must, however, render this part of the Arctic Osean very susceptible to the cooling influence of an unusial southivard drift of polar ice, and the paculiarities of this year's summer were exactly those which such an abnormal cooling of the sea would produce. These were evidently exaggerated over the open sea a little further north. During the few fine days we had while going round the island of Magerö, the sun was visible until about iI or II.30 P.M., but on approaching the north horizon it dipped into a mist-bank which hung with apparent permanency over the northermmost and most distant part of the sea. As we were desirous of sceing the actual orb of the sun quite at midnight, this rejeated disappcarance jist at the critical time was of course especially noted. I afterwarls learned that on these same nights, when the midnight sun thus played at hide-and-seek with us over the Arctic Ocean, it was clearly seen by spectators further south, who had a land of near coast horizon.

These facts, in conjunction with "the important information" given by Capt. Gray, justify us, I think, in looking forward very bopefully for important results from the proposed Arctic Expedition, and afford strong reasons for avoidling any possible source of delay that might stand in the way of an early start to make full use of next summer.

W. Mattieu Williams

\section{Zoological Gardens, Regent's Parik}

I MUST trouble you with a few words in reply to your correa spondents "Viator" and Mr. C. Traill (vol. xi. p. 67.)

It is quite true that our gardens in the Regent's Park are "too small in ara." We have for many years endeavoured to get them enlarged; but all we have sacceeded in obtaining is the slip of land on the north side of the Regent's Canal, where the new North Intrance has been made. If "Viator" has any influcnce with the First Commissioner of Works, and can persuade him to grant us a further extension on the south side, we shill be truly gratefu.

I admit also that the larger carnivora are at present badily housed, and that their clens are much too confined. This, however, will, I trust, be remedied by the erection of the new Lions' House, which will be commenced early next year.

The plan of establishing a second Gurden for breeding purposes out of London was adopted by the Council some years ago, but was not ficund to answer. It has, however, many advantages, and may be again tried when our funds shall permit of it.

"Viator" finds great fault with our drainge. He cannot be aware that the Sanitary Authorities of the district, who have been much cxercised in this matter, have pronounced us free from all blame.

Finally, I may say, without any wish to disparage the continental garlens (with all of which I am well accuainted), that none of them can vie with those of this Society in the extent, variety, and completeness of its living collection, or in the rarity of many of the objects exhibite?. That this collection is appreciated by the public is fully evident from the ycarly increas. ing number of visitors and the continual augmentation of the list of meinbers.

As regards the remarlis of Mr. Traill, I have to observe that the Society's "Procedings" contnin several papers by the Secretaries and Superintendents of the Gardens relating to points in the economy of the animals in then; and that the Prosector (whose office was created mainly with the lope of atilising the collection more completely in a scientific point of view) has lately devoted considerable attention to this subject, on which he will, no doubt, ultimately give us the benefit of his observations.

Dcc. $\mathrm{I}$

P. L, SClater

\section{Utilisation of Aquaria}

I SHALI be glad if you will allow me to use your columns as a medium of inquiry with regard to the Brighton and Manchester Aquaria. Are there any arrangements in force already, or contemplated, whereby these fine institutions can be utilised for the promotion of zoological research? If I am not mistaken, the 